\title{
Physiological characterization of Streptococcus bovis mutants that can resist 2-deoxyglucose-induced lysis
}

\author{
Daniel R. Bond, Ben M. Tsai and James B. Russell
}

Author for correspondence: James B. Russell. Tel: +1 607255 4508. Fax: +1 6072553904. e-mail: jbr8@cornell.edu

Section of Microbiology, Wing Hall, Cornell University and Agricultural Research Service, US Department of Agriculture, Ithaca, NY 14853, USA
Streptococcus bovis JB1 does not normally lyse, but stationary phase lysis can be induced by including 2-deoxyglucose (2DG) in the growth medium. Isolates deficient in glucose/2DG phosphotransferase activity (PTS-) also lysed when 2DG was present $\left(\right.$ Lys $^{+}$) and this result indicated that 2DG phosphorylation via the PTS was not an obligate requirement for 2DG-induced lysis. Cells and cell walls from 2DG-grown cultures lysed faster when proteinase $K$ was added, but glucose-grown cultures and cell walls were not affected. A lipoteichoic acid (LTA) extract (aqueous phase from hot phenol treatment) from glucose-grown cells inhibited the lysis of 2DG-grown cultures, but a similar extract prepared from 2DG-grown cells was without effect. Thin-layer chromatography and differential staining indicated that wild-type and Lys $^{+}$PTS $^{-}$cells incorporated 2DG into LTA, but lysis-resistant cultures (Lys ${ }^{-}$PTS $^{+}$and Lys $^{-}$PTS $^{-}$) did not. LTA from lysis-resistant (Lys- ${ }^{-}$PTS $^{+}$and Lys $^{-}$PTS $^{-}$) cells grown with glucose and 2DG also prevented 2DG-dependent lysis of the wild-type. LTA could not inhibit degradation of cell walls isolated from 2DG-grown cultures, but LTA inhibited the lysis of Micrococcus lysodeikticus (Micrococcus luteus) cells that were exposed to supernatants from 2DG-grown S. bovis cultures. Group D streptococci (including $S$. bovis) normally have an $\alpha-1,2$ linked glucose disaccharide (kojibiose) in their LTA, but kojibiose cannot be synthesized from 2DG. This observation suggested that the kojibiose moiety of LTA was involved in autolysin inactivation. Wild-type S. bovis had ATP- as well as PEP-dependent mechanisms of 2DG phosphorylation and one lysis-resistant phenotype (LysPTS $^{-}$) had reduced levels of both activities. However, the Lys- ${ }^{-}$PTS $^{+}$phenotype was still able to phosphorylate 2DG via ATP and PEP and this result indicated that some other step of 2DG incorporation into LTA was being inhibited. Based on these results, growth in the presence of 2DG appears to prevent synthesis of normal LTA, which is involved in the regulation of autolytic enzymes.

Keywords: Streptococcus bovis, 2-deoxyglucose, cell lysis, lipoteichoic acid

\section{INTRODUCTION}

Streptococcus bovis is a facultative anaerobe that is normally found in the rumen of cattle and the colon of simple stomached animals. In the rumen, S. bovis overgrowth is associated with a decline in rumen $\mathrm{pH}$, indigestion and even death of the animal (Hungate $e t$ al., 1952). S. bovis can also infect human tissues and has

Abbreviations: 2DG, 2-deoxyglucose; LTA, lipoteichoic acid; PTS, phosphotransferase system. been associated with general bacteraemia, heart valve infections and deterioration of the colon wall during colon cancer (Kupferwasser et al., 1988; Zarkin et al., 1990).

Previous work indicated that $S$. bovis lysis could be triggered by the non-metabolizable glucose analogue, 2-deoxyglucose (2DG) (Russell \& Wells, 1997). 2DGinduced lysis was only observed if it was added to growing cultures and 2DG had no effect on stationaryphase cultures. 2DG-treated cells had weakened cell walls that were more susceptible to degradation by 
lysozyme and it appeared that 2DG was preventing inactivation of cell-wall-hydrolysing enzymes (Russell \& Wells, 1997).

Wild-type S. bovis cells have a glucose phosphotransferase (PTS) system that can also phosphorylate 2DG (Martin \& Russell, 1986) and 2DG 6-phosphate can be dephosphorylated by a phosphatase (Cook et al., 1995). This cycle of phosphorylation and dephosphorylation can slow growth and de-energize the cell (Thompson, 1987). S. bovis also has a facilitated diffusion system for glucose, allowing mutants lacking the glucose-PTS to still grow rapidly on glucose (Russell, 1990; Cook \& Russell, 1994).

In many Gram-positive organisms, lipoteichoic acids (LTAs) have been shown to inactivate cell-wall-degrading enzymes and LTAs are often glycosylated by UDP-glucose that arises from glucose 1-phosphate (Fischer, 1988, 1994). Saccharomyces can produce 2DG 1-phosphate and UDP-2DG (Biely et al., 1971), but synthesis of these phosphorylated sugars has not been investigated in prokaryotes. However, because group D streptococcal LTAs contain glucose residues linked via an $\alpha-1,2$ bond (kojibiose and kojitriose) (Wicken \& Baddiley, 1963; Wicken \& Knox, 1975), we hypothesized that 2DG-induced lysis might be mediated via synthesis of abnormal LTAs.

The following experiments sought to (1) select and characterize 2DG-resistant mutants, (2) examine the relationship between sugar phosphorylation and 2DGinduced lysis, (3) determine if LTAs could counteract 2DG-induced lysis and (4) monitor the possible incorporation of 2DG into LTAs of S. bovis.

\section{METHODS}

Cell growth. Streptococcus bovis JB1 was routinely grown under $\mathrm{O}_{2}$-free $\mathrm{CO}_{2}$ at $39^{\circ} \mathrm{C}$ in basal medium containing $\left(1^{-1}\right)$ :

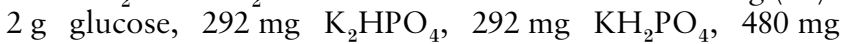
$\left(\mathrm{NH}_{4}\right)_{2} \mathrm{SO}_{4}, 480 \mathrm{mg} \mathrm{NaCl}, 100 \mathrm{mg} \mathrm{MgSO}_{4} .7 \mathrm{H}_{2} \mathrm{O}, 64 \mathrm{mg}$ $\mathrm{CaCl}_{2} \cdot 2 \mathrm{H}_{2} \mathrm{O}, 500 \mathrm{mg}$ cysteine $\mathrm{HCl}, 1 \mathrm{~g}$ Trypticase $(\mathrm{BBL}$ Microbiology Systems), $4 \mathrm{~g} \mathrm{Na}_{2} \mathrm{CO}_{3}$ and $0.5 \mathrm{~g}$ yeast extract. The medium was adjusted to $\mathrm{pH} 6.7$ and the final $\mathrm{pH}$ was never less than 6.5. When indicated, 2-deoxy-D-glucose (2DG) was added prior to inoculation at a concentration of $2 \mathrm{mg}$ $\mathrm{ml}^{-1}$. Growth was monitored via changes in $\mathrm{OD}_{600}$ in $18 \times 150$ $\mathrm{mm}$ tubes that were sealed with butyl rubber stoppers.

Lysis assays. Lysis was typically monitored by following decreases in optical density after $S$. bovis cultures had reached stationary phase. Proteinase K, when indicated, was added directly to stationary-phase cultures at a final concentration of $1 \mathrm{mg} \mathrm{ml}$. When cell extracts or semi-purified LTA was added, additions were made at the onset of stationary phase, at a concentration of $75 \mu \mathrm{g}$ carbohydrate $(\mathrm{mg} \text { cell protein })^{-1}$ unless otherwise indicated.

Lysis was also monitored by suspending Micrococcus lysodeikticus (Micrococcus luteus) cells (ATCC 4698; Sigma) in supernatants from lysed $S$. bovis cultures and measuring changes in optical density. S. bovis $\mathrm{Lys}^{+}$cultures were grown in the presence of 2DG, allowed to lyse for $48 \mathrm{~h}$ and centrifuged anoxically $(15 \mathrm{~min}, 3500 \mathrm{~g})$ to remove residual cells. After supernatants were transferred to anoxic tubes, $M$. lysodeikticus cells were added from a concentrated stock to a final $\mathrm{OD}_{600}$ of 1.0 (approx. $150 \mathrm{mg}$ cell protein $\mathrm{l}^{-1}$ ) and tubes were incubated at $39^{\circ} \mathrm{C}$. When cell extract or semi-purified LTA was added [75 $\mu \mathrm{g}$ carbohydrate $\left.(\mathrm{mg} \text { cell protein })^{-1}\right]$, tubes with an equivalent amount of sodium phosphate buffer served as a control.

For cell wall lysis assays, cell walls were isolated essentially according to Blackman et al. (1998). Cells grown in the presence or absence of $2 \mathrm{DG}$ were harvested and washed three times in $\mathrm{ddH}_{2} \mathrm{O}+0.5 \mathrm{mM}$ PMSF $\left(10000 \mathrm{~g}, 5 \mathrm{~min}, 4^{\circ} \mathrm{C}\right)$. Concentrated cells were subjected to two passes through a pre-cooled French pressure cell $(138000 \mathrm{kPa})$, centrifuged for $15 \mathrm{~min}\left(3000 \mathrm{~g}, 4^{\circ} \mathrm{C}\right.$ ) (to pellet unbroken cells) and the top two-thirds of this suspension was carefully removed for pelleting of cell walls $\left(25000 \mathrm{~g}, 4^{\circ} \mathrm{C}\right)$. Walls were washed in $100 \mathrm{mM} \mathrm{NaCl}$ twice to remove loosely associated proteins and each time care was taken to not resuspend the more solid pellet consisting of contaminating cells and membrane vesicles. Walls were washed twice in $50 \mathrm{mM}$ Tris $/ \mathrm{HCl}+1 \mathrm{mM} \mathrm{MgCl}$ buffer, $\mathrm{pH} 6 \cdot 5$, and resuspended to a final $\mathrm{OD}_{600}$ of approximately 10 . Lysis was immediately assayed by diluting walls in $50 \mathrm{mM}$ Tris $/ \mathrm{HCl}+1 \mathrm{mM} \mathrm{MgCl}_{2}+1 \mathrm{mM}$ dithiothreitol, $\mathrm{pH}$ $6 \cdot 5$, and monitoring the decrease in $\operatorname{OD}_{600}\left(39^{\circ} \mathrm{C}\right)$. Rates of lysis were lower in the absence of dithiothreitol. The purity of these preparations (presence of walls and not vesicles) was confirmed by addition of lysozyme, which caused a rapid decrease in the $\mathrm{OD}_{600}$ to less than $5 \%$ of original levels. Some walls were also assayed after one freeze-thaw cycle (storage at $-20^{\circ} \mathrm{C}$ ). Further freeze-thaw cycles reduced lytic activity and altered protein profiles as visualized by SDS-PAGE (see below). Proteinase K, when indicated, was added at a final concentration of $1 \mathrm{mg} \mathrm{ml}^{-1}$. When cell extract or semi-purified LTA was added, $200 \mu \mathrm{g}$ carbohydrate was added per $\mathrm{OD}_{600}$ unit of cell walls.

Selection of lysis-resistant and glucose-PTS-deficient phenotypes. 2DG-treated (2 mg glucose $\mathrm{ml}^{-1}$ and $\left.2 \mathrm{mg} 2 \mathrm{DG} \mathrm{ml} \mathrm{m}^{-1}\right) S$. bovis JB1 cultures were transferred at least seven times $(<1 \%$ inoculum) every 6 or $72 \mathrm{~h}$. As transport of 2DG via the glucose-PTS slows growth, $6 \mathrm{~h}$ transfers selected for cells able to grow rapidly due to a lack of the glucose/2DG-PTS. Longer (72 h) transfers selected for lysis-resistant cells, while retaining pressure to keep the PTS due to its role in recovery from starvation. Once cultures yielded a desired phenotype (PTS or Lys ${ }^{-}$), they were streaked onto an agar plate containing basal medium and $10 \mathrm{mg} \mathrm{ml}^{-1}$ each of glucose and 2DG. A small number of individual colonies were restreaked, tested for PTS activity and lysis sensitivity and one of each phenotype (PTS ${ }^{-}$or Lys $^{-}$) was retained. The PTS ${ }^{-}$culture $\left(\mathrm{Lys}^{+} \mathrm{PTS}^{-}\right.$) was subjected to a series of 72 -h transfer intervals to obtain the other phenotype (Lys ${ }^{-}$PTS $^{-}$). The stability (lack of reversion) of each isolate was monitored by transferring cultures without 2DG every $12 \mathrm{~h}$ and testing each successive culture for 2DGdependent lysis and PTS activity.

PTS assays. PEP-dependent sugar phosphorylation was assayed enzymically by a method that measures pyruvate production via lactate dehydrogenase (Martin \& Russell, 1986). Cells were harvested $(10 \mathrm{ml})$ during exponential growth by centrifugation $\left(10000 \mathrm{~g}, 10 \mathrm{~min}, 4^{\circ} \mathrm{C}\right)$ and washed in 100 $\mathrm{mM}$ sodium/potassium phosphate buffer $\left(25 \mathrm{mM} \mathrm{Na}{ }^{+}\right.$, $75 \mathrm{mM} \mathrm{K}^{+}, 5 \mathrm{mM} \mathrm{MgCl}$, $1 \mathrm{mM}$ dithiothreitol, $\mathrm{pH} 7 \cdot 2$ ). Cells were resuspended in the same buffer and stored on ice. Cells $(250 \mu \mathrm{l})$ were treated with $8 \mu \mathrm{l}$ toluene/ethanol mixture (1:9, $\mathrm{v} / \mathrm{v})$, subjected to vigorous agitation for $1 \mathrm{~min}$ and used immediately. All PTS assays were performed at $39^{\circ} \mathrm{C}$, corrections were made for non-specific NADH oxidase 
activity and specific activities were determined under enzymelimiting conditions (protein concentration versus activity was linear). Each assay typically contained $\left(\mathrm{ml}^{-1}\right): 10 \mu \mathrm{l}$ of the toluenized cells (approx. $10 \mu \mathrm{g}$ protein), 9 units L-lactic dehydrogenase, 0.84 $\mu \mathrm{mol}$ DTT, $4.2 \mu \mathrm{mol} \mathrm{MgCl}_{2}, 8.6 \mu \mathrm{mol}$ PEP, $0.17 \mu \mathrm{mol}$ NADH, $1.6 \mu \mathrm{mol}$ sugar, $75 \mu \mathrm{mol}$ potassium phosphate and $25 \mu \mathrm{mol}$ sodium phosphate.

Phosphorylation of 2DG. Cultures $(40 \mathrm{ml})$ were washed as described for the PTS assay and resuspended in $2 \mathrm{ml}$ sodium/ potassium phosphate buffer (approx. $6 \mathrm{mg}$ protein $\mathrm{ml}^{-1}$ ). Concentrated cells were toluenized with $30 \mu$ toluene/ethanol $(1: 9, \mathrm{v} / \mathrm{v})$ for $1 \mathrm{~min}$ and immediately divided into two tubes containing 2DG $(10 \mathrm{mM})$ plus either ATP or PEP $(10 \mathrm{mM})$. Cells were incubated for $30 \mathrm{~min}$ at $39^{\circ} \mathrm{C}$ and centrifuged $(10000 \mathrm{~g}, 10 \mathrm{~min})$. The supernatant was frozen and analysed via TLC (see below).

LTA extracts. LTA was extracted from cells using hot aqueous phenol (Sijtsma et al., 1990; Hogg et al., 1997). Cultures (4 l) were centrifuged $\left(10000 \mathrm{~g}, 15 \mathrm{~min}, 25^{\circ} \mathrm{C}\right)$, washed in phosphate buffer $\left(10 \mathrm{mM} \mathrm{Na}_{2} \mathrm{HPO}_{4}, 1 \mathrm{mM} \mathrm{MgCl}{ }_{2}, \mathrm{pH} 7 \cdot 5\right)$ and concentrated to a final concentration of approx. $0.4 \mathrm{~g}$ cells $\mathrm{ml}^{-1}$. The cell suspension was stirred with an equal amount of pre-warmed $85 \%$ phenol $\left(65^{\circ} \mathrm{C}, 90 \mathrm{~min}\right)$ and centrifuged $\left(10000 \mathrm{~g}, 20 \mathrm{~min}, 25^{\circ} \mathrm{C}\right)$ to obtain phase separation. The water layer was removed, extracted with an equal volume of chloroform/isoamyl alcohol $(24: 1, \mathrm{v} / \mathrm{v})$, centrifuged again and the water layer retained. Crude extract (or phosphate buffer processed in a similar fashion with phenol and chloroform as a control) was added to stationary-phase cultures $(0.05-0.5 \mathrm{ml}$ into $10 \mathrm{ml})$ and 2DG-induced lysis was monitored as described above. The extract was further purified by treatment with RNase and DNase $\left(20 \mu \mathrm{g} \mathrm{ml} l^{-1}\right.$ each, $30^{\circ} \mathrm{C}, 8 \mathrm{~h}$ ), extracted twice with cold phenol/ chloroform/ethanol $(25: 24: 1$, by vol.) and dialysed $24 \mathrm{~h}$ (3000 kDa cut-off) against 10000 volumes of Tris buffer (10 mM Tris/ $\mathrm{HCl}, 1 \mathrm{mM} \mathrm{MgCl}_{2}, \mathrm{pH} 7 \cdot 5,4{ }^{\circ} \mathrm{C}$ ) to remove solvents and nucleic acid fragments. Assuming $2 \mu \mathrm{mol}$ glucose equivalents (mg LTA) ${ }^{-1}$ (Kessler et al., 1983), extractions from all cell types yielded approximately $2-4 \mathrm{mg} \mathrm{LTA}(\mathrm{g} \text { cells })^{-1}$.

TLC. Equal amounts of anthrone-reactive material or sugar standards (typically 1-3 $\mu$ g hexose equivalent) were applied to spots $1 \mathrm{~cm}$ apart on TLC plates (Merck Art. 5737 silica gel $60 /$ kieselguhr $\mathrm{F}_{254}$ pre-coated, layer thickness $0.25 \mathrm{~mm}$ ) and separated by immersing the bottom $1 \mathrm{~cm}$ of the plate in n-propanol/ethyl acetate/water (7:1:4, by vol.). Dried plates were sprayed with an anisaldehyde-based reagent (27 ml ethanol, $0.3 \mathrm{ml}$ acetic acid, $1.5 \mathrm{ml}$ sulfuric acid, $1.5 \mathrm{ml}$ p-anisaldehyde) and placed in a $110^{\circ} \mathrm{C}$ oven for $5 \mathrm{~min}$. Under these conditions and at the concentrations typically used, standards of the sugars glucose, fructose, galactose, glucosamine, ribose, xylose, arabinose and 2DG all stained as unique colours against a pink background, while maltose, cellobiose, lactose and melibiose stained similar to glucose. To confirm the presence of 2DG in extracts, duplicate plates were stained with an anthrone-based stain (prepared by dissolving $0.3 \mathrm{~g}$ anthrone in $10 \mathrm{ml}$ acetic acid and mixing with $20 \mathrm{ml}$ ethanol, $3 \mathrm{ml}$ phosphoric acid and $1 \mathrm{ml}$ water) and placed in a $110^{\circ} \mathrm{C}$ oven for $5 \mathrm{~min}$. Under these conditions and at the concentrations typically used, no colour was observed for glucose, galactose, glucosamine, maltose, cellobiose, lactose or melibiose, but 2DG stained dark blue. Fructose, ribose, xylose and arabinose stained shades of yellow.

TLC was also used to monitor glucose and 2DG phosphorylation. Supernatants from toluenized cells incubated with 2DG and either ATP or PEP as the phosphoryl donor were applied to similar TLC plates and separated using the same solvent mixture. Under these conditions, glucose could be separated from UDP-glucose and glucose 6-phosphate migrated similar to glucose 1-phosphate. Thus, the production of 2DG phosphates could be monitored, but we could not determine if the product was 2DG 1-phosphate or 2DG 6-phosphate.

Other analyses. Cell wall samples for SDS-PAGE were added directly to sample buffer (final concentration 1\% SDS, 5\% glycerol, $10 \mathrm{mM}$ Tris/HCl, $10 \mathrm{mM}$ DTT), boiled for $3 \mathrm{~min}$, centrifuged at $14000 \mathrm{~g}$ for $15 \mathrm{~min}$ to remove cell walls and subjected to electrophoresis on $12 \%$ polyacrylamide gels under denaturing conditions according to Laemmli (1970). Carbohydrate in cell extracts was assayed by the anthrone method (Bailey, 1958) using glucose as standard and nucleic acids did not interfere with this assay. Protein was determined using the NanoOrange reagent (Molecular Probes).

\section{RESULTS}

\section{Lysis and selection of PTS and lysis-deficient phenotypes}

When S. bovis JB1 was incubated with glucose and 2DG, the cells grew nearly as fast as untreated controls, but lysis was observed after the cultures reached stationary phase ( $>90 \%$ lysis after $48 \mathrm{~h}$ ). Significant lysis was only observed if $2 \mathrm{DG}$ was present during the entire growth phase. If $2 \mathrm{DG}$ was added in late exponential phase or during stationary phase, little lysis was observed (Fig. 1). Proteinase $K$ accelerated the lysis of $S$. bovis cultures grown with 2DG ( $80 \%$ lysis after 24 h), but it had no effect on glucose-grown cultures (data not shown). Cell walls prepared from wild-type cultures grown with glucose were stable for long periods of time

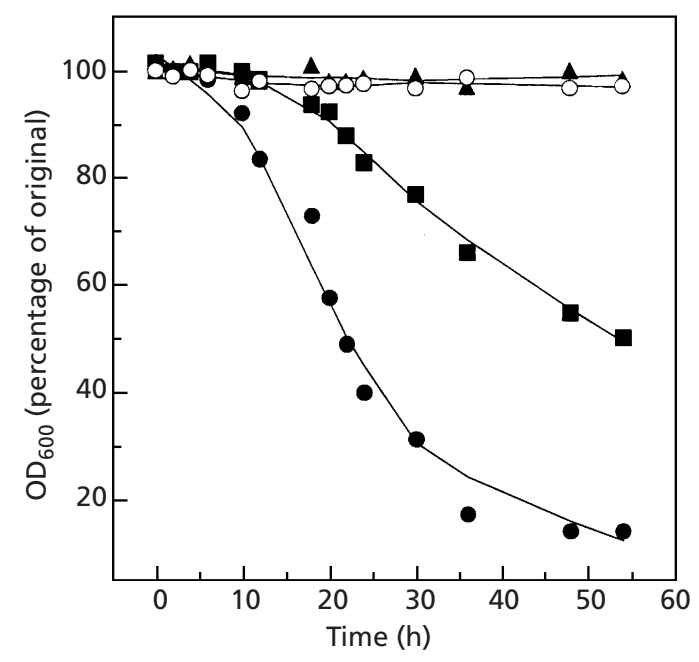

Fig. 1. The effect of 2DG $\left(2 \mathrm{mg} \mathrm{m}^{-1}\right)$ addition on the optical density of $S$. bovis cells grown with glucose $\left(2 \mathrm{mg} \mathrm{ml}^{-1}\right)$. 2DG was added at the onset of stationary phase $(\bigcirc)$, midexponential phase $(\boldsymbol{\square})$ or at inoculation (0). Controls with no 2DG ( $\boldsymbol{\Delta})$ are also shown. 


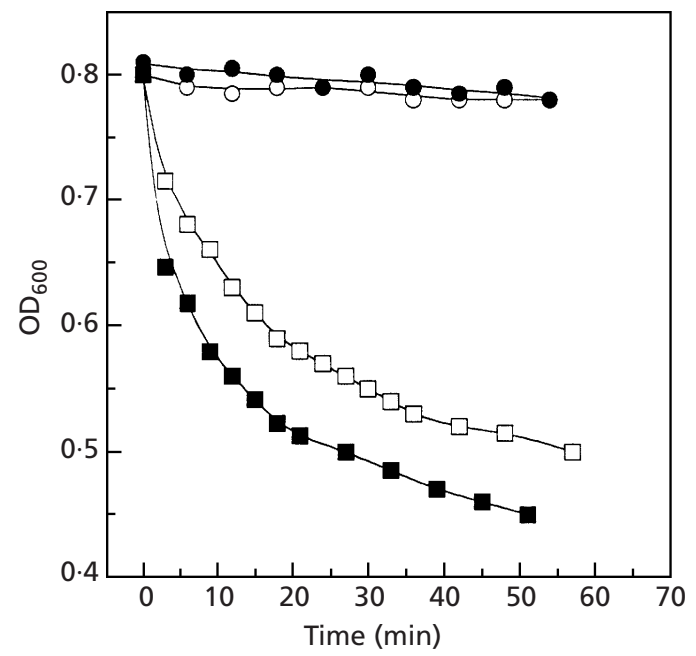

Fig. 2. The optical density of $S$. bovis cell walls that were isolated from glucose-grown $(O, 0)$ and glucose + 2DG-grown $(\square, \boldsymbol{a})$ cultures and incubated in Tris buffer $(50 \mathrm{mM}, \mathrm{pH} 7 \cdot 0$, $1 \mathrm{mM} \mathrm{MgCl} 2,1 \mathrm{mM}$ dithiothreitol, $39^{\circ} \mathrm{C}$ ). Filled symbols show cell walls that were treated with proteinase $\mathrm{K}\left(1 \mathrm{mg} \mathrm{ml}^{-1}\right)$.

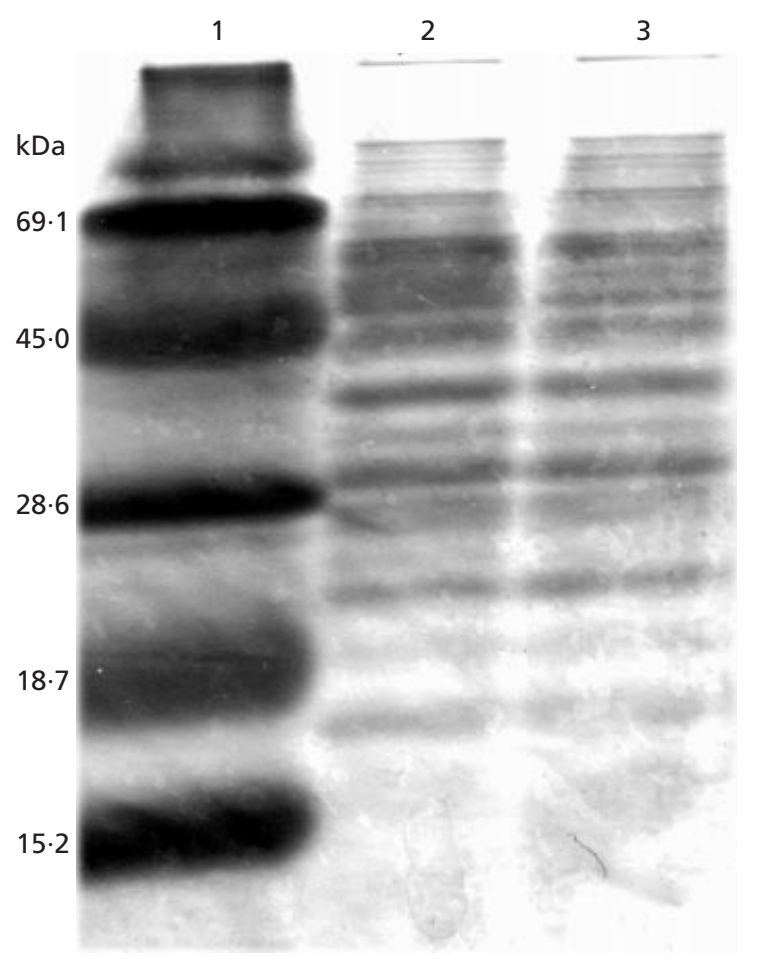

Fig. 3. SDS-PAGE of proteins associated with cell walls isolated from $S$. bovis. Lanes: 1, molecular mass standard; 2, cell walls from cultures grown with glucose; 3, cell walls from cultures grown with glucose plus 2DG.

at $39^{\circ} \mathrm{C}$ (Fig. 2). Cell walls prepared from cultures grown with glucose and 2DG decayed rapidly if they were incubated at $39^{\circ} \mathrm{C}$ and this initial decay could also be accelerated by proteinase K. PAGE gels indicated that cells grown with glucose or glucose plus 2DG had similar cell-wall-associated proteins (Fig. 3).

When wild-type $S$. bovis JB1 $\left(\mathrm{Lys}^{+} \mathrm{PTS}^{+}\right)$was transferred every $6 \mathrm{~h}$ with glucose and 2DG, cells lost their glucose- and 2DG-PTS activities, but 2DG-dependent lysis was still observed $\left(\mathrm{Lys}^{+} \mathrm{PTS}^{-}\right.$, Table 1$)$. When the Lys $^{+}$PTS $^{-}$culture was transferred with glucose and 2DG every $72 \mathrm{~h}$, a lysis-resistant, PTS $^{-}$phenotype emerged $\left(\mathrm{Lys}^{-} \mathrm{PTS}^{-}\right)$. Wild-type cells $\left(\mathrm{Lys}^{+} \mathrm{PTS}^{+}\right)$that were grown with glucose and 2DG every $72 \mathrm{~h}$ also became lysis-resistant, but PTS activity was retained $\left(\right.$ Lys $^{-}$PTS $^{+}$). Further work was based on cultures obtained via colony re-isolation from each culture $\mathrm{Lys}^{+}$ $\left.\mathrm{PTS}^{+}, \mathrm{Lys}^{-} \mathrm{PTS}^{+}, \mathrm{Lys}^{+} \mathrm{PTS}^{-}, \mathrm{Lys}^{-} \mathrm{PTS}^{-}\right)$. These cultures did not revert to the wild-type phenotype when cultures were allowed to grow for 50 generations without selective pressure.

Toluene-permeabilized wild-type and $\mathrm{Lys}^{-} \mathrm{PTS}^{+}$cells phosphorylated 2DG when PEP was present and a phosphorylated 2DG derivative could be detected on TLC plates sprayed with an anisaldehyde stain (Fig. 4). Virtually no PEP-dependent 2DG phosphorylation was detected with the $\mathrm{Lys}^{+} \mathrm{PTS}^{-}$and $\mathrm{Lys}^{-} \mathrm{PTS}^{-}$cells. When ATP was added as the phosphoryl donor, the wild-type, Lys $^{-}$PTS $^{+}$and Lys $^{+}$PTS $^{-}$cells produced a 2DG phosphate derivative, but the Lys $^{-}$PTS $^{-}$isolate produced less of this product. No 2DG phosphorylation was detected from any cell type with GTP, ITP or UTP as the donor.

\section{LTA extract}

When wild-type cells (grown without 2DG) were treated with $85 \%$ hot phenol, the water soluble extract prevented 2DG-dependent lysis of wild-type cells (Fig. 5). An extract from wild-type cells grown with glucose and 2DG was approximately 100 -fold less effective than extract prepared from cells grown with only glucose (Fig. 6). The crude extracts had an abundance of anthrone-reactive carbohydrate $\left(>500 \mathrm{mg} \mathrm{l}^{-1}\right)$, nucleic acids $\left(>100 \mu \mathrm{g} \mathrm{ml}^{-1}\right)$ and small amounts of protein $\left(<50 \mu \mathrm{g} \mathrm{m}{ }^{-1}\right)$, but nuclease treatments, phenol/ chloroform precipitations and dialysis removed additional protein $\left(<20 \mu \mathrm{g} \mathrm{ml}^{-1}\right)$ and nucleic acids $\left(<50 \mu \mathrm{g} \mathrm{ml} l^{-1}\right)$, while the anthrone-reactive material remained. The dialysed extract from glucose-grown cells was as effective in preventing the 2DG-dependent lysis of $\mathrm{Lys}^{+}$strains as the crude extract, and dialysed extracts of lysis-sensitive strains $\left(\mathrm{Lys}^{+}\right)$grown with 2DG still did not prevent wild-type lysis.

Dialysed extracts prevented 2DG-dependent lysis of $S$. bovis cells that were treated with proteinase $K$ and these extracts could even stabilize cells that had already initiated an increased lysis rate (Fig. 7). Dialysed extracts did not affect the initial degradation rate of cell walls prepared from 2DG-grown cultures and the difference in cell wall autolysis was not nearly so dramatic after $48 \mathrm{~h}$ as seen in whole cells treated with similar extracts 
Table 1. PTS activities and lysis sensitivities of four different phenotypes of S. bovis

Data are the means of three determinations \pm SD.

\begin{tabular}{|lrcc|}
\hline Phenotype & Glucose-PTS* & 2DG-PTS* & Percentage lysis after 48 h $\dagger$ \\
\hline Wild-type $\left(\right.$ Lys $^{+}$PTS $\left.^{+}\right)$ & $668 \cdot 7 \pm 95 \cdot 1$ & $696 \cdot 5 \pm 43 \cdot 6$ & $92 \cdot 2 \pm 4 \cdot 2$ \\
Lys $^{+}$PTS & $46 \cdot 3 \pm 10 \cdot 4$ & $22 \cdot 5 \pm 12 \cdot 1$ & $90 \cdot 3 \pm 3 \cdot 1$ \\
Lys $^{-}$PTS $^{+}$ & $329 \cdot 6 \pm 21 \cdot 6$ & $366 \cdot 2 \pm 45 \cdot 1$ & $5 \cdot 7 \pm 5 \cdot 1$ \\
Lys $^{-}$PTS & $20 \cdot 8 \pm 11 \cdot 2$ & ND & $8 \cdot 3 \pm 3 \cdot 1$ \\
\hline
\end{tabular}

*Expressed as nmol NADH oxidized (mg protein) ${ }^{-1} \mathrm{~min}^{-1}$ in the presence of the sugar indicated, corrected for non-specific NADH oxidase activity. ND, Not detected.

† Percentage decrease in $\mathrm{OD}_{600}$ after $48 \mathrm{~h}$ compared to that at the end of exponential growth phase.

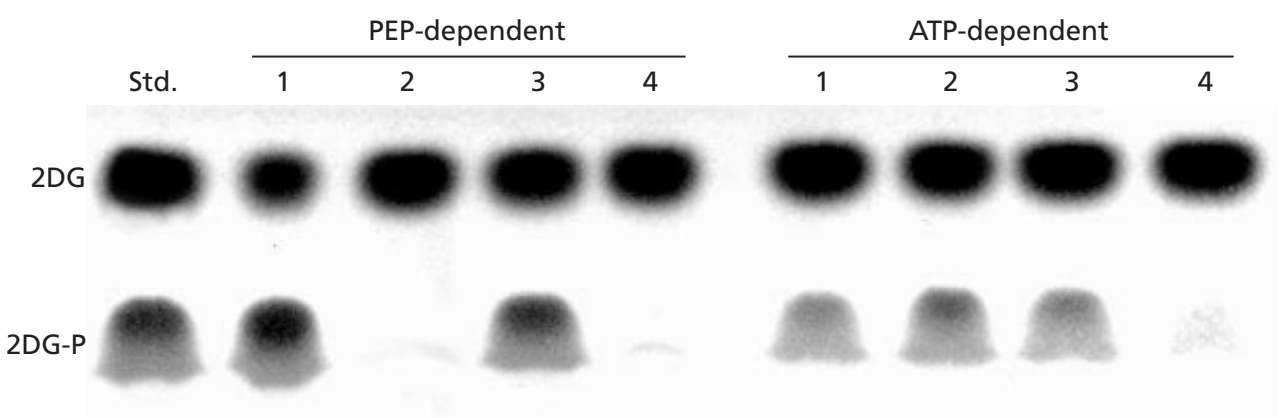

Fig. 4. $T L C$ of $2 D G$ and $2 D G$ phosphate (2DG-P) produced by $S$. bovis cells. Toluene-treated cells were incubated with $2 D G$ and either PEP or ATP as a phosphoryl donor. Lanes: 1, wild-type cells; 2, Lys ${ }^{+}$PTS $^{-} ; 3$, Lys $^{-}$PTS $^{+}$; 4 , Lys PTS $^{-}$. The standard (Std.) was a mixture of 2DG and 2DG 6-phosphate.

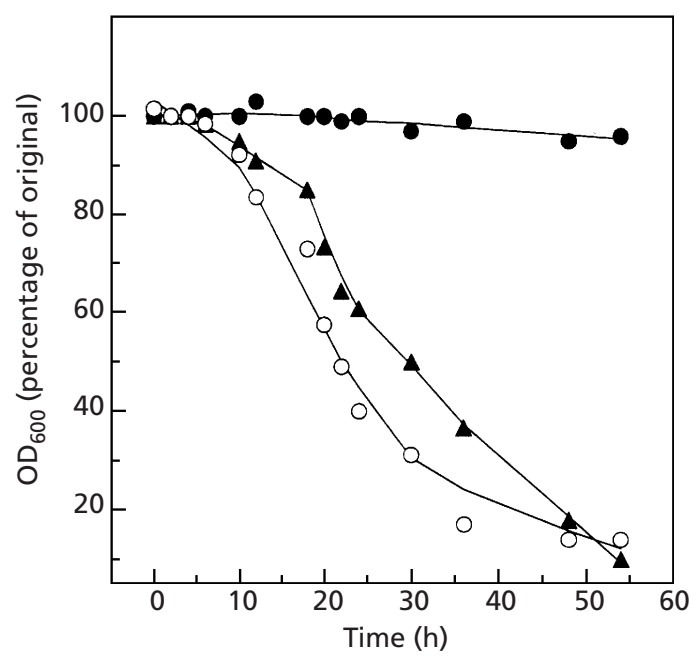

Fig. 5. The effect of semi-purified LTA extracts on the optical density of stationary phase $S$. bovis cells grown with 2DG. Extracts were derived from wild-type cells grown on glucose (0) or wild-type cells grown with glucose and 2DG $(\boldsymbol{\Delta})$. Controls with no extract $(\bigcirc)$ are also shown. The extracts were added to achieve $75 \mu \mathrm{g}$ carbohydrate per mg cell protein.

(Table 2). M. lysodeikticus cells that were incubated in media with or without $2 \mathrm{DG}$ at $39^{\circ} \mathrm{C}$ did not lyse and supernatant from $48 \mathrm{~h}$ wild-type $S$. bovis cultures grown

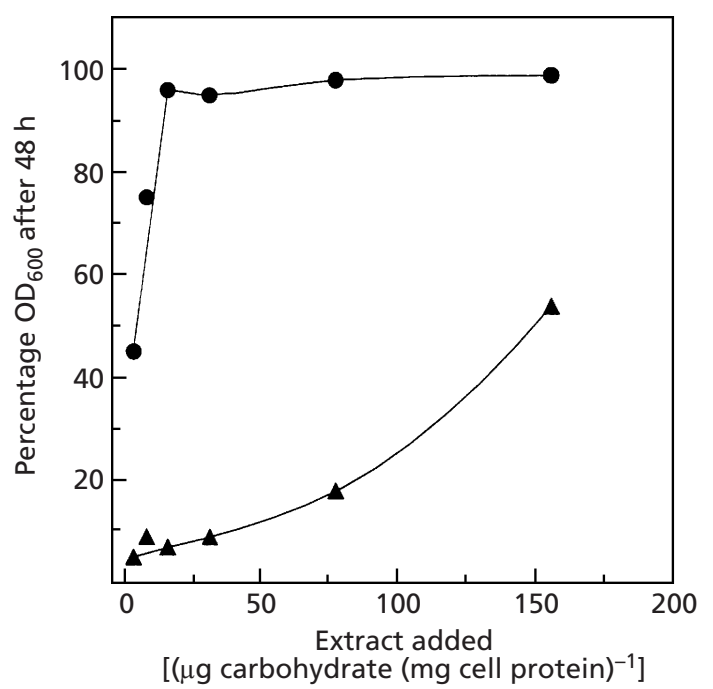

Fig. 6. The effect of semi-purified LTA extracts on the lysis of stationary phase $S$. bovis cells grown with 2DG. Extracts were derived from wild-type cells grown on glucose (0) or wild-type cells grown with glucose and 2DG ( $\boldsymbol{\Delta})$.

on glucose had little effect on these cells (data not shown). Supernatants from $S$. bovis cultures grown on glucose and 2DG promoted the lysis of M. lysodeikticus 


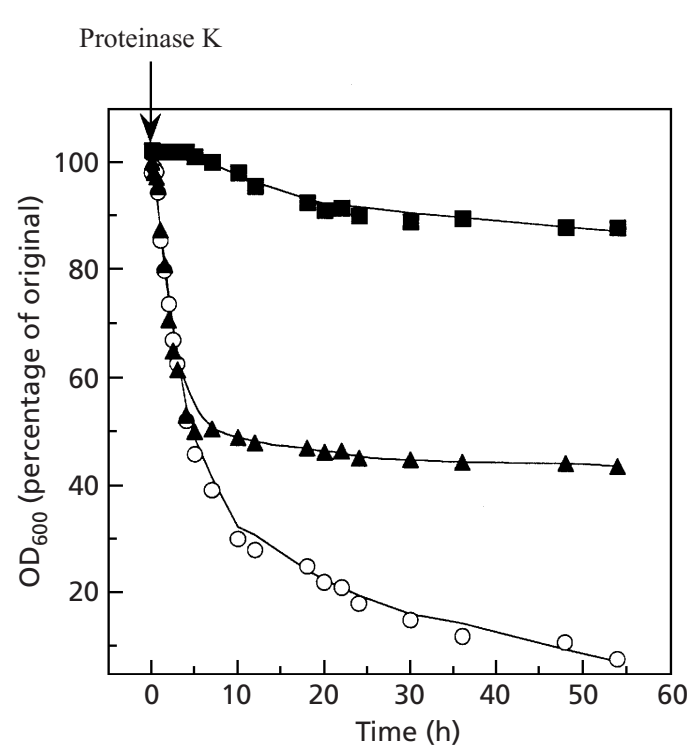

Fig. 7. The effect of semi-purified LTA extracts on the optical density of stationary phase $S$. bovis cells grown with 2DG and treated with proteinase K. Extracts were added at $0(\boldsymbol{\square})$ or 5 (A) $\mathrm{h}$ after proteinase $\mathrm{K}$ addition. Controls with no extract (O) are also shown. Extracts [75 $\mu \mathrm{g}$ carbohydrate (mg cell protein $)^{-1}$ ] were derived from wild-type cells grown on glucose alone. Cells which did not receive extract or proteinase $\mathrm{K}$ are shown Fig. 1 and Fig. 5.

Table 2. Effect of semi-purified LTA extract from glucose-grown cells on lysis of $S$. bovis cells, isolated cell walls and $M$. lysodeikticus cells

Data are the means of two determinations $\pm S D$.

\begin{tabular}{|lrrc|}
\hline Treatment & \multicolumn{3}{c|}{ Percentage $\mathrm{OD}_{600}$ remaining after $48 \mathrm{~h}$} \\
\cline { 2 - 4 } & S. bovis* $^{*}$ & Cell wall $†$ & M. lysodeikticus $\ddagger$ \\
\hline None & $8 \cdot 4 \pm 3 \cdot 1$ & $33 \cdot 6 \pm 5 \cdot 2$ & $45 \cdot 3 \pm 4 \cdot 8$ \\
+ LTA extract & $94 \cdot 1 \pm 4 \cdot 2$ & $40 \cdot 2 \pm 6 \cdot 3$ & $96 \cdot 3 \pm 3 \cdot 3$ \\
\hline
\end{tabular}

$* S$. bovis cells grown with glucose $+2 \mathrm{DG}$.

† Cell walls isolated from 2DG-grown cultures of S. bovis.

$\ddagger$ M. lysodeikticus cells + supernatant from 2DG-grown S. bovis cultures.

cells and this lysis could also be inhibited by the dialysed extract (Table 2).

\section{Incorporation of 2DG into LTA}

An anisaldehyde stain was able to detect both 2DG and glucose on TLC plates, but these compounds migrated and stained differently (blue vs green) (Fig. 8a, lane 1). The ability of TLC to differentiate these sugars could be enhanced by the use of an anthrone-based stain. The anthrone stain reacted strongly with 2DG (Fig. 8b, lane 1 ), but did not produce any colour with glucose. When phenol extracts from wild-type $S$. bovis grown on glucose were applied to the TLC plates and stained with anisaldehyde, several sugar-containing bands were observed that stained similar to glucose (Fig. 8a, lane 2). These bands were not visible if an anthrone-based strain was used (Fig. 8b, lane 2). When wild-type cells were grown with glucose and 2DG, the major carbohydratecontaining band migrated faster (Fig. 8a, lane 3) and stained blue rather than green (indicative of 2DG). This band also reacted strongly and stained similar to 2DG when the anthrone-based stain was used (Fig. 8b, lane 3). Sugar-containing substances from the lysis-sensitive, PTS $^{-}$isolate $\left(\mathrm{Lys}^{+} \mathrm{PTS}^{-}\right)$migrated the same and had the same colour as those from wild-type cells (Fig. 8a, b, lanes 4). The lysis-resistant $\left(\mathrm{Lys}^{-} \mathrm{PTS}^{+}\right.$and $\mathrm{Lys}^{-} \mathrm{PTS}^{-}$) extracts had anisaldehyde-reactive carbohydrate that stained positive for glucose, but reacted poorly with the 2DG-detecting anthrone-based stain (Fig. 8a, b, lanes 5 and 6).

\section{DISCUSSION}

The rumen is an ideal habitat for the growth of anaerobic bacteria, but ${ }^{15} \mathrm{~N}$ labelling experiments indicate that as much as $33 \%$ of the microbial protein turns over before it leaves the rumen (Nolan, 1975). Ruminal protozoa can engulf and digest some bacteria, but Krebs et al. (1989) demonstrated that microbial turnover was nearly as great in protozoa-free sheep. The rumen environment also contains bacteriophage and aneroplasmas, which could contribute to bacterial lysis, but pure cultures of many rumen species also lyse rapidly (Wells \& Russell, 1996b). S. bovis JB1 is a relatively stable bacterium, but previous work indicated that it would lyse if 2DG was included in the growth medium (Russell \& Wells, 1997). This observation made it possible to study an aspect of lysis regulation in $S$. bovis.

Bacterial stability is bolstered by peptidoglycan, but peptidoglycan-degrading enzymes are needed for many important processes, including cell wall assembly (Shockman \& Barrett, 1983), cell separation (Foster, 1995), flagellar synthesis (Pooley \& Karamate, 1984) and sporulation (Foster, 1992). Some of these enzymes can cause the lysis of intact cells (Shockman \& Barrett, 1983) and these 'autolysins' must be carefully regulated during growth and after the cells have reached stationary phase. Bacillus has autolysins that are regulated at the transcriptional level and are only transcribed during sporulation (Foster, 1992), but post-translational regulation is also commonly observed (Jolliffee et al., 1980; Buist et al., 1988).

Autolysins of bacteria are strongly associated with the cell wall, where they can be further regulated by proteolytic inactivation (Rogers et al., 1984; Wells \& Russell, 1996a; Buist et al., 1988). Conversely, some autolysins are secreted as proenzymes and can be activated by proteinases (Shockman et al., 1967; Kariyama \& Shockman, 1992). PAGE gels indicated that $S$. bovis cultures grown with or without 2DG had 


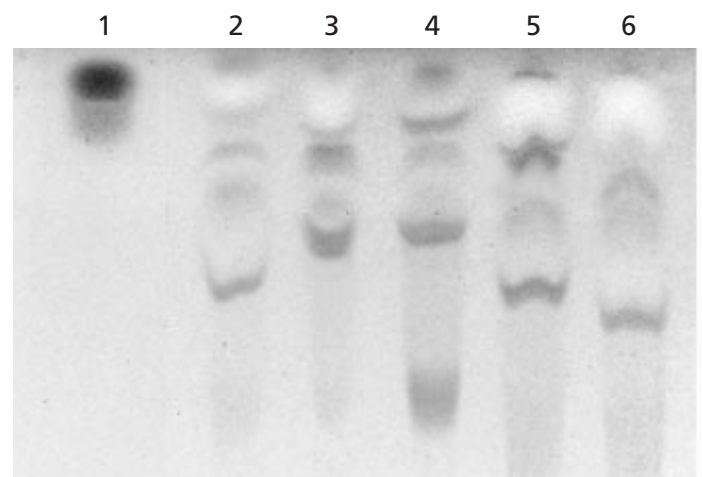

(a)

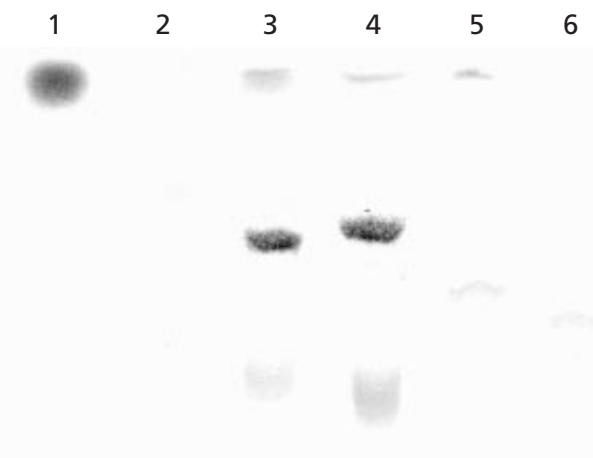

(b)

Fig. 8. TLC of LTA extracts. Identical plates were sprayed with an anisaldehyde stain (a) or an anthrone-based stain (b). Lanes: 1, a standard mixture of 2DG (upper spot) and glucose (lower); 2, LTA extract from wild-type cells grown only with glucose; 3, extract from wild-type cells grown with glucose and 2DG; 4, extract from Lys ${ }^{+}$PTS $^{-}$grown with glucose and 2DG; 5, extract from Lys ${ }^{-}$PTS $^{+}$grown with glucose and 2DG; 6, extract from Lys ${ }^{-}$PTS $^{-}$grown with glucose and 2DG.

similar cell-wall-associated proteins and the 2DG-dependent lysis of $S$. bovis could be accelerated by proteinases. Based on these observations, 2DG-grown cells seemed to have the same autolysins as glucosegrown cells and growth with 2DG was interfering with autolytic regulation.

Previous workers demonstrated that autolytic inactivation can be affected by other cell wall components, such as LTA (Höltje \& Tomasz, 1975 ; Diederick Meyer \& Wouters, 1987; Cleveland et al., 1976a; Roger et al., 1984; Fischer, 1988; Jolliffee et al., 1980). Most Grampositive species have LTA in their cell wall (Fischer, 1994) and in streptococci, LTAs are commonly found as diacylglycerolipid-anchored chains of 1,3-linked poly(glycerolphosphate) (Fischer, 1988). The C-2 of each glycerol residue in the LTA backbone is often substituted by sugars and/or D-alanine esters (Fischer et al., 1981). LTA has been shown to inhibit autolysins from bacilli (Rogers et al., 1984; Wecke et al., 1997), enterococci (Cleveland et al., 1976a), streptococci (Holtje \& Tomasz, 1975) and staphylococci (Fischer et al., 1981), and in some cases, the degree of inhibition has been correlated with alterations at the C-2 position of the LTA glycerolphosphate chain (Fischer et al., 1981; Wecke et al., 1997).

Organisms that react with the Lancefield group D antibody have LTAs substituted with either kojibiose or kojitriose, an $\alpha-1,2$ linked glucose di- or trisaccharide (Wicken \& Knox, 1975, Kessler et al., 1984). Because it is chemically impossible to synthesize kojibiose from 2DG, it appeared that the 2DG-dependent lysis of $S$. bovis (a group D streptococcus) was being mediated via an alteration in LTA substitution which allowed increased autolysin activity. This idea was supported by several observations: (1) 2DG was detected in LTA extracts from wild-type cells grown with 2DG, (2) 2DG was not detected in LTA extracts of lysis-resistant isolates, even if 2DG was added to the growth medium, (3) glucose-containing LTA extracts could prevent 2DG- dependent lysis in S. bovis, even when it was stimulated by proteinase $\mathrm{K}$ and (4) 2DG-containing LTA extracts could not prevent 2DG-dependent lysis. LTA inhibited the lysis of M. lysodeikticus cells that were suspended in supernatants from 2DG-treated $S$. bovis cultures, but LTA was not able to reduce the degradation of $S$. bovis cell walls that were obtained from 2DG-treated cultures. These latter findings indicate that LTA is effective in intact cells, but this effect may be lost when cells are sheared and cell walls repeatedly washed in sodium chloride.

Because most bacterial glucose kinases cannot recognize 2DG, net 2DG phosphorylation has often been used as an index of PTS activity (Romano et al., 1979). TLC confirmed that PTS ${ }^{-}$isolates had reduced PEP-dependent 2DG phosphorylation, but significant ATP-dependent 2DG phosphorylation was still detected in wildtype $S$. bovis and one of the PTS $^{-}$isolates. The idea that ATP-dependent 2DG phosphorylation might play a role in 2DG-dependent lysis was supported by the observation that one of the lysis-resistant isolates $\left(\mathrm{Lys}^{-} \mathrm{PTS}^{-}\right)$ had significantly less activity than wild-type cells. The other lysis-resistant isolate $\left(\mathrm{Lys}^{-} \mathrm{PTS}^{+}\right.$) retained PTS activity as well as ATP-dependent 2DG phosphorylation and this indicated that accumulation of intracellular 2DG phosphate alone does not trigger lysis (Prasad \& Freese, 1974). This $\mathrm{Lys}^{-} \mathrm{PTS}^{+}$isolate still produced normal glucose-containing LTA, even if 2DG was present, indicating that some later step in LTA synthesis had been modified to exclude 2DG.

Autolytic enzymes can also be inhibited by amphiphiles such as cardiolipin and phosphatidyl glycerol (Höltje \& Tomasz, 1975; Cleveland et al., 1976b; Diederick Meyer \& Wouters, 1987), bringing the specificity of LTAs as autolysin inhibitors into question. Some LTAs have alanine residues extending from the glycerophosphate backbone or carbohydrate side chains and this substitution decreases the ability of LTAs to inhibit autolysins from Staphylococcus aureus and Bacillus 
subtilis (Fischer et al., 1981; Wecke et al. 1997). These labile alanine residues are reportedly lost under the conditions used in our extraction procedures (Fischer \& Koch, 1981), but extracts from S. bovis maintained similar activity at all stages of purification, suggesting that alanine substitution was not responsible for differences in autolysin-LTA interactions in this organism. Glycosyl substitution, another structural feature that could confer specificity, did not significantly affect autolysis in S. aureus (Fischer et al. 1981). However, increased glucose substitution of LTA (caused by chloramphenicol treatment) has been correlated with a decrease in the autolysis of Enterococcus faecalis (Pooley \& Shockman, 1970; Kessler et al., 1983). When S. bovis was grown in 2DG-containing medium, it incorporated 2cDG into its LTA and this LTA lost virtually all of its ability to inhibit autolysis of whole cells. These results and the observation that isolates resistant to lysis did not incorporate 2DG into their LTA, indicate that the carbohydrate side chain of LTA may be an important feature of autolysin regulation in S. bovis.

\section{DISCLAIMER}

Proprietary or brand names are necessary to report factually on available data; however, the USDA neither guarantees nor warrants the standard of the product and the use of the name by the USDA implies no approval of the product and exclusion of others that may be suitable.

\section{REFERENCES}

Bailey, R. W. (1958). The reaction of pentoses with anthrone. Biochem J 68, 669-672.

Biely, P., Krátky, Z., Kovarík, J. \& Bauer, S. (1971). Effect of 2deoxyglucose on cell wall formation in Saccharomyces cerevisiae and its relation to cell growth inhibition. J Bacteriol 107, 121-129.

Blackman, S. A., Smith, T. J. \& Foster, S. J. (1988). The role of autolysins during vegetative growth of Bacillus subtilis 168. Microbiology 144, 73-82.

Buist, G., Venema, G. \& Kok, J. (1988). Autolysis of Lactococcus lactis is influenced by proteolysis. J Bacteriol 180, 5947-5953.

Cleveland, R. F., Wicken, A. J., Daneo-Moore, L. \& Shockman, G. D. (1976a). Inhibition of wall autolysis in Streptococcus faecalis by lipoteichoic acid and lipids. J Bacteriol 126, 192-197.

Cleveland, R. F., Wicken, A. J., Daneo-Moore, L. \& Shockman, G. D. (1976b). Effect of lipoteichoic acid and lipids on lysis of intact cells of Streptococcus faecalis. J Bacteriol 127, 1582-1584.

Cook, G. M. \& Russell, J. B. (1994). Alternative strategies of 2deoxyglucose resistance and low affinity glucose transport in the ruminal bacteria, Streptococcus bovis and Selenomonas ruminantium. FEMS Microbiol Lett 123, 207-212.

Cook, G. M., Ye, J. J., Russell, J. B. \& Saier, M. H. (1995). Properties of two sugar phosphate phosphatases from Streptococcus bovis and their involvement in inducer expulsion. J Bacteriol 177, 7007-7009.

Diederick Meyer, P. \& Wouters, J. T. M. (1987). Lipoteichoic acid from Bacillus subtilis subsp. Niger WM, isolation and effects on cell wall autolysis and turnover. J Bacteriol 169, 973-980.

Fischer, W. (1988). Physiology of lipoteichoic acids in bacteria. Adv Microb Physiol 29, 235-247.
Fischer, W. (1994). Lipoteichoic acids and lipoglycans. In New Comprehensive Biochemistry, vol. 27, pp. 199-214. Edited by J.M. Ghuysen \& R. Hakenback. Amsterdam: Elsevier.

Fischer, W. \& Koch, H. U. (1981). Alanine ester substitution and its effect on the biological properties of lipoteichoic acids. In Chemistry and Biological Activities of Bacterial Surface Amphiphiles, pp. 181-194. Edited by G. D. Shockman \& A. J. Wicken. New York: Academic Press.

Fischer, W., Rösel, P. \& Koch, H. U. (1981). Effect of alanine ester substitution and other structural features of lipoteichoic acids on their inhibitory activity against autolysins of Staphylococcus aureus. J Bacteriol 146, 467-475.

Foster, S. J. (1992). Analysis of the autolysins of Bacillus subtilis 168 during vegetative growth and differentiation by using renaturing polyacrylaminde gel electrophoresis. J Bacteriol 174, 464-470.

Foster, S. J. (1995). Molecular characterization and functional analysis of the major autolysin of Staphylococcus aureus 8325/4. J Bacteriol 177, 5723-5725.

Hogg, S. D., Whiley, R. A. \& De Soet, J. J. (1997). Occurrence of lipoteichoic acid in oral streptococci. Int J Syst Bacteriol 47, 62-66.

Höltje, J.-V. \& Tomasz, A. (1975). Lipoteichoic acid: a specific inhibitor of autolysin activity in Pneumococcus. Proc Natl Acad Sci USA 72, 1690-1694.

Hungate, R. E., Dougherty, R. W., Bryant, M. P. \& Cello, R. M. (1952). Microbiological and physiological changes associated with acute indigestion in sheep. Cornell Vet 42, 423-449.

Jolliffee, L. K., Doyle, R. J. \& Streips, U. N. (1980). Extracellular proteases modify cell wall turnover in Bacillus subtilis. J Bacteriol 141, 1199-1208.

Kariyama, R. \& Shockman, G. D. (1992). Extracellular and cellular distribution of muramindase-2 and muramidase-1 of Enterococcus hirae ATCC 9790. J Bacteriol 174, 3236-3241.

Kessler, R. E., Wicken, A. J. \& Shockman, G. D. (1983). Increased carbohydrate substitution of lipoteichoic acid during inhibition of protein synthesis. J Bacteriol 155, 138-144.

Kessler, R. E., Duke, J. \& Goldstein, I. J. (1984). Interaction of antikojibiose antibody with the lipoteichoic acids from Streptococcus faecalis and Streptococcus faecium. Infect Immun 46, 279-281.

Krebs, G. L., Leng, R. A. \& Nolan, J. V. (1989). Microbial biomass and production rates in the rumen of faunated and fauna-free sheep on low protein fibrous feeds with or without nitrogen supplementation. In The Roles of Protozoa and Fungi in Ruminant Digestion, p. 295. Edited by J. V. Nolan, R. A. Leng \& D. I. Demeyer. Armidale, Australia: Penambul Books.

Kupferwasser, I., Darius, H., Mueller, A. M., Mohr-Kahaly, S., Westermeier, T., Olert, H., Erbel, R. \& Meyer, J. (1988). Clinical and morphological characteristics in Streptococcus bovis endocarditis: A comparison with other causative microorganisms in 177 cases. Heart 80, 276-280.

Laemmli, U. K. (1970). Cleavage of structural proteins during the assembly of the head of bacteriophage T4. Nature 227, 680-685.

Martin, S. A. \& Russell, J. B. (1986). Phosphoenolpyruvate-dependent phosphorylation of hexoses by rumen bacteria: Evidence for the phosphotransferase system of transport. Appl Environ Microbiol 52, 1348-1352.

Nolan, J. v. (1975). Quantitative models of nitrogen metabolism in sheep. In Digestion and Metabolism in the Ruminant, pp. 416-431. Edited I. W. MacDonald \& A. C. I. Warner. Armidale, Australia: University of New England Publishing Unit.

Pooley, H. M. \& Karamate, H. (1984). Genetic analysis of autolysin 
deficient and flagellaless mutants of Bacillus subtilis. J Bacteriol 160, 1123-1129.

Prasad, C. \& Freese, E. (1974). Cell lysis of Bacillus subtilis caused by intracellular accumulation of glucose-1-phosphate. J Bacteriol 118, 1111-1122.

Rogers, H. J., Taylor, C., Rayter, S. \& Ward, J. B. (1984). Purification and properties of autolytic endo- $\beta$ - $N$-acetylglucosamidase and the $\mathrm{N}$-acetylmuramyl-L-alanine amidase from Bacillus subtilis strain 168. J Gen Microbiol 130, 2395-2402.

Romano, A. H., Trifoneand, J. D. \& Brustolon, M. (1979). Distribution of the phosphoenolpyruvate: glucose phophotransferase system in fermentative bacteria. J Bacteriol 139, 93-97.

Russell, J. B. (1990). Low affinity, high capacity system of glucose transport in the ruminal bacterium Streptococcus bovis: evidence for a mechanism of facilitated diffusion. Appl Environ Microbiol 56, 3304-3307.

Russell, J. B. \& Wells, J. E. (1997). The ability of 2-deoxyglucose to promote the lysis of Streptococcus bovis JB1 via a mechanism involving cell wall stability. Curr Microbiol 35, 299-304.

Shockman, G. D. \& Barrett, J. F. (1983). Structure, function and assembly of cell walls of gram-positive bacteria. Annu Rev Microbiol 37, 501-527.

Shockman, G. D., Thompson, J. S. \& Conover, M. J. (1967). The autolytic enzyme system of Streptococcus faecalis. II. Partial characterization of the autolysin and its substrate. Biochemistry 6, 1054-1064.
Sijtsma, L., Wouters, J. T. M. \& Hellingwerf, K. J. (1990). Isolation and characterization of lipoteichoic acid, a cell envelope component involved in preventing phage adsorption, from Lactococcus lactis subsp. cremoris SK110. J Bacteriol 172, 7126-7130.

Thompson, J. (1987). Regulation of sugar transport and metabolism in lactic acid bacteria. FEMS Microbiol Rev 46, 221-231.

Wecke, J., Madela, K. \& Fischer, W. (1997). The absence of Dalanine from lipoteichoic acid and wall teichoic acid alters surface charge, enhances autolysis and increases susceptibility to methicillin in Bacillus subtilis. Microbiology 143, 2952-2960.

Wells, J. E. \& Russell, J. B. (1996a). The effect of growth and starvation on the lysis of the ruminal cellulolytic bacterium Fibrobacter succinogenes. Appl Environ Microbiol 62, 1342-1346.

Wells, J. E. \& Russell, J. B. (1996b). Why do many ruminal bacteria die and lyse so quickly? J Dairy Sci 79, 1487-1495.

Wicken, A. J. \& Baddiley, J. (1963). Structure of intracellular teichoic acids from group D streptococci. Biochem J 87, 54-62.

Wicken, A. J. \& Knox, K. W. (1975). Lipoteichoic acids: a new class of bacterial antigen. Science 187, 1161-1167.

Zarkin, B. A., Lillemoe, K. D., Cameron, J. L., Effron, P. N., Magnuson, T. H. \& Pitt, H. A. (1990). The triad of Streptococcus bovis bacteremia, colonic pathology and liver disease. Ann Surg 211, 786-792.

Received 23 February 1999; revised 25 May 1999; accepted 7 June 1999. 